\title{
INTERDISCIPLINARY INTEGRATION ON THE BASIS OF THE GEOMETRICAL CONSTITUENT OF THE NATURAL SCIENTIFIC PICTURE OF THE WORLD
}

\author{
Elena Ermak \\ Pskov State University, Russian Federation
}

\begin{abstract}
Fragmentariness of the picture of the world in majority modern students is a significant obstacle in the development of their scientific worldview. The lack of integrity of the image of the universe is aggravated by the prevalence of the clip-on thinking among students, which prevents the students from fully acquiring fundamental classical education. The formation of an integral scientific picture of the world is necessary for the realization of an independent productive research activity. In whatever field this activity is carried out, it is closely related to the creation of spatial representations and the mental manipulation of them in the process of solving various problems. Spatial representations are ordered in the mind of the learner on the basis of the geometric component of the natural science picture of the world. Integrated content courses such as "Introduction to the Modern Geometry of the Universe" while teaching of students should be combined with the implementation of the principle of interdisciplinary integration in the development of the educational program, carried out on the basis of the geometric component of the natural-science picture of the world.
\end{abstract}

Keywords: teaching students; interdisciplinary integration; spatial representations; geometrical component of the natural-science picture of the world.

\section{Introduction}

The success of mastering the educational program of the technical, physicalmathematical, natural-science and a number of other areas of preparation chosen by the student of the university depends to a large extent on the level of development of the student's spatial representations. Mental creation of spatial images and operating them in accordance with a particular practical task, with a particular creative idea, is necessary for a person in various fields of professional activity, in productive interaction with the real world. The role of geometry in improving the spatial representations of the learner is extremely important at the same time, both at the stage of schooling, and with conscious mastery of the content of various academic disciplines in the university. An analysis of previously completed dissertation research on the problems of theory and methods of developing students' spatial thinking (Якиманская \& Карымова, 2007; 
Ermak, 2018. Interdisciplinary Integration on the Basis of the Geometrical Constituent of the Natural Scientific Picture of the World

Гусев \& Докшукин, 2012; Подходова, 2017) led to the conclusion that spatial representations of schoolchildren can fully develop only if the interdisciplinary links are realized. In particular, in dissertation of E. A. Ermak (Ермак, 1991) theoretically and experimentally substantiates the fact that spatial representations of high school students can not be effectively developed on the basis of only one, although extremely important for this development subject, as geometry. It is necessary to implement interdisciplinary connections in the training of high school students, and, first of all, the links of geometry with physics, astronomy, geography. A successful form of the implementation of these links are optional items of integrative content, such as "Introduction to the modern geometry of the universe," which allows organically combining Euclidean geometric representations with expediently and "dosed" elements of non-Euclidean geometries on the basis of solving interdisciplinary problems. Of course, the systematization of the spatial representations of university students, the further improvement of their spatial thinking also require interdisciplinary integration in the teaching of students. The revealing of optimal conditions for the implementation of this integration is still a very far from final solution to the problem in the theory and methodology of teaching students. The main research activities during the 7 year were new training tools also neck to be interdisciplinary integration on the basis of the geometrical constituent on the natural scientific picture of the world. Value practical: development of spatial thinking of students in the university.

\section{The main part of the paper}

The main objectives of training students in the university are:

1) development of a scientific worldview;

2) a conscious and strong mastery of professional knowledge, skills, competencies - in accordance with the chosen specialty, or - the direction, profile of training;

3) creative development of the personality of each student.

At the same time, first of all, the most important result of the student's education should be his willingness to show confidently, effectively and productively his personal and professional qualities in a rapidly changing modern world. The Information Society equips the student with new powerful means of replicating, distributing, transforming and storing information. On the one hand, it provides its advantages in the field of operating with colossal data sets, and on the other hand it gives rise to illusions about its own cognitive abilities. Actually, a significant part of modern students are not fully aware of the difference 
between the concepts of "information" and "knowledge", "competence", believing that it is quite enough to remember that "from where you can download" this or that material appropriate to the program of the discipline under study. Unfortunately, at the same time, students do not even have a question about the degree of reliability of the information obtained in this way. Furthermore, this information, not being actively mastered by a student based on his subjective experience and individual features of thinking, imaginative perception of the world, does not become an element of theoretical knowledge, nor a component of the practical competence of this student. The student can only formally reproduce such information, but it's not able to productively use, apply in solving practical problems within the discipline and, especially, at the interdisciplinary level. Consequently, the first of the above goals of teaching students in a university the development of a scientific worldview - is not achieved. Their thinking in this case is doomed to remain a clip-on, educational-cognitive activity - possessing a low degree of awareness, practical actions-manipulative, situational (in the worst sense of the word). At the same time, one can speak about the fundamental, classical education of a graduate of a university only on the condition that in his mind there is an integral image of the universe, that he has formed a modern scientific picture of the world.

The actual modernization of the system of higher education has already led to the fact that, along with traditional methods, the means and forms of teaching students, the practice of mastering various academic disciplines is increasingly introducing collective ways of realization of educational-cognitive and educational-research activity of students: business and role-playing games with professional content, analysis of a concrete situation (case-study), etc. Participation of students in this kind of activity, of course, has a positive impact on the development of their communicative competence, gives the opportunity to improve their teamwork skills, to show both flexibility in behavior and creativity. But at the same time, knowledge, skills, competencies, student views can re-main fragmentary, disordered. They do not acquire personal meaning for this particular student, and consequently, there are insurmountable difficulties in their application, in the student's independent educational and cognitive and productive research activity on their basis.

In this way, the creation in the university an educational environment in which the intellectual and creative potential of students would be fully revealed, their abilities for independent professional activity would develop, is now a difficult problem. Teachers of various disciplines and the organizers of the educational process in the university are advisable to solve this problem not from case to case, but systematically. They should design joint activities on a scientific basis, carrying out reliable predictions of its results. System-activity approach in 
Ermak, 2018. Interdisciplinary Integration on the Basis of the Geometrical Constituent of the Natural Scientific Picture of the World

the subject and professional training of students can be a scientific basis, ensuring a high level of effectiveness of these activities.

The system-activity approach in mastering students in academic disciplines requires, in turn, the implementation of the principle of interdisciplinary integration in teaching. This integration can be either predominantly scientific, if, for example, the "Mathematics" profile is trained in the direction of "Pedagogical Education”, or, predominantly, artistic, if training is provided for, for example, future designers The conception of artistic integration (Дутцев, 2013) and the revealing of fundamentally new architectural creations in imaginative creations, the practical realization of their integration into the surrounding natural and anthropogenic environment (Vytuleva, 2009) will find in this case the application in the training of students on an interdisciplinary basis. In any case, it is necessary to understand and express the attitude of "man-Universe" with the help of those tools that most correspond to this category of students. Otherwise, the development of the scientific worldview of students will only pass sporadically, and the holistic, harmonious image of the universe will be replaced in their minds by an unordered set of everyday and mythologized notions, mainly stereotyped. At the same time, for the successful self-realization of each student as an individual in a modern, dynamically changing world, an organic combination of figurative and logical components in the composition of their spatial representations is necessary. The consciousness of each student has a unique set of spatial representations, depending on the subjective experience of the student and the individual characteristics of his spatial thinking. Abilities in the field of spatial thinking, as shown in psychology (Yakimanskaya \& Karimova, 2007), are identified through special tests. At the same time, the closest is the connection between abilities in the field of creation and mental manipulation with spatial images and abilities for geometric activity, success in solving geo-metrical problems. In turn, according to research in the field of theory and methods of teaching geometry (Ермак, 2003, 2005), the development of spatial thinking of high school students and students of the university can be effectively implemented on the basis of the geometric component of the natural science picture of the world. In the process of teaching, this picture, the most significant features of which are highlighted in this research is a means for ordering and improving the spatial representations of students, independently of the direction and profile of the training, on what specialty is mastered. Anyway, the most important features of the geometric component of the natural-science picture of the world are:

1. The representation of the universal principle of symmetry and its various demonstrations in the structure of the universe. 
2. Primary representation about the curvature of space as a difference between its geometric properties and the properties of space expressed by Euclidean geometry.

3. The representation of the closest relationship between space and time.

4. The representation of the curvature of time-space in an alternating gravitational field.

5. The representations of the existence of spaces of dimension different from three, both Euclidean and non-Euclidean.

6. The representations about the use of non-Euclidean geometries in the creation of models of the universe as a whole.

7. The representation of the relativity of any geometric component of the natural scientific picture of the world, its correspondence to the level of cognition of reality and the peculiarities of the language of expression of the results of this cognition at each particular stage of the development of mankind.

Individual features of the student's spatial thinking and the specificity of his spatial representations are taken into account in the learning process due to the fact that the geometric component of the natural scientific picture of the world, along with the invariant "core", always has a variable "shell" through which interdisciplinary links are realized. In addition, the student should be able to get acquainted with the above-mentioned most essential features of the geometric component of the natural-science picture of the world at the level of mathematical rigor in the presentation of the material, which is more in line with his abilities in the field of spatial thinking. These abilities, as evidenced by the results of psychological research, are largely determined by innate factors. Such persistent characteristics of human spatial thinking, as a type of operating with spatial images, the university teacher should be able to diagnose, in order to take into account further training, and not to try to change it through influence through the content and technology of teaching students. Thus, students who by nature have weak abilities for the mental creation of spatial images and operate them in order to solve various practical or creative tasks, have the first type of operating with spatial images. This category of students can be familiarized with the most essential features of the geometric component of the natural-science picture of the world when implementing the historical-genetic approach in the process of their teaching. Accordingly, the mastering of the material, the implementation of interdisciplinary integration in this case takes place among students at the general cultural level, with minimal use of the mathematical apparatus. Most students (about $70 \%$ of their total number) have an average level of development of spatial thinking and, accordingly, have a second type of operating with spatial images. It is expedient for these students to use an interdisciplinary and practical approach when acquainting themselves with the most essential features of the geometric 
Ermak, 2018. Interdisciplinary Integration on the Basis of the Geometrical Constituent of the Natural Scientific Picture of the World

component of the natural scientific picture of the world. They can master the material at a figurative and practical level, solving various tasks that require interdisciplinary integration, primarily of a meaningful nature. Such peculiarities of students' training correspond optimally to the implementation of the systemactivity approach in mastering the academic disciplines. The importance of the system-activity approach for the formation and development of the scientific worldview of students was mentioned above.

Particular attention should be given to students gifted in the field of spatial thinking, who have a third type of operating with spatial images. But they are, and on the average - every fifth student, find themselves in an unfavorable position, relative to the rest, in conditions conducive to the creative development of the individual, the implementation of professional training, the formation of a modern scientific worldview. So, if we are talking about students of physics and mathematics faculty who are gifted in the field of spatial thinking, these students are able to consider the most essential features of the natural science picture of the world, using a mathematical language, in fact, not different from that used in modern exact and natural sciences. This category of students has already expressed certain scientific interests, which allow implementing various signmathematical approaches in mastering the most important features of the geometric component of the natural-science picture of the world. Each of these students requires an individual trajectory in the implementation of interdisciplinary integration in the learning process. For students gifted in the field of spatial thinking, there should be real opportunities for mastering a variety of elective courses, the study of which would enable them to find a worthy practical, creative use in solving the diverse complex problems of their unique personal characteristics and outstanding natural abilities.

Taking into account that, as a rule, relatively little time is spent on classroom activities in the course programs (most often - not more than 72 hours), it is advisable to provide conditions for increasing the level of internal motivation for independent continuation of the student's work on the material that is the basis for the elective course. When mastering the content of the elective course, the student may have original ideas for further independent creative activity, requiring the use of talent in the field of spatial thinking, the mental creation and transformation of geometric representations. As effective means of creating positive motivation and real implementation of interdisciplinary integration, the elective disciplines are used. 


\section{Conclusion}

Individual features of the student's spatial thinking and the specificity of his spatial representations are taken into account in the learning process due to the fact that the geometric component of the natural scientific picture of the world, along with the invariant "core", always has a variable "shell" through which interdisciplinary links are realized. Using the developed method (Ermak E., 2013) of developing spatial thinking for over ten years on the Physics and Mathematics Faculty and the Faculty of Educational Technologies and Design of the Pskov State University (participate a training or new education programs up to 500 students), interdisciplinary integration is carried out on the basis of the geometric component of the natural-science picture of the world. The training is conducted in the frame-work of integrated courses and elective courses.

\section{References}

Vytuleva, K. (2009). Iced Architects. European architectural history network, 3, 38-41.

Гусев, В. А., \& Докшукин, 3. П. (2012). Новая стратегия обучения геометрии в основной школе. Педагогическое образование и наука, 3, 22-25.

Дуцев, М. В. (2013). Концепция «полей» художественной интеграции в новейшей архитектуре. Вестник Московского государственного строительного университета, 2, 22-28.

Ермак, Е. А. (1991). Развитие пространственных представлений старшеклассников при изучении геометрии с использованием элементов неевклидовых геометрий. Автореферат диссертации на соискание учёной степени кандидата педагогических наук. Санкт-Петербург.

Ермак, Е. А. (2003). Развитие геометрической составляющей естественнонаучной картины мира старшеклассников. Известия Российского государственного педагогического университета имени А. И. Гериена, 3 (6), 204-214.

Ермак, Е. А. (2005). Геометрическая составляющая естественнонаучной картины мира старшеклассников. Диссертация на соискание учёной степени доктора педагогических наук. Санкт-Петербург.

Ермак, Е. А. (2013). О подготовке магистрантов к деятельности по развитию пространственного мышления обучающихся. Вестник Псковского государственного университета. Серия «Естественные и физикоматематические науки». Выпуск 3, 100-103.

Подходова, Н. С. (2017). Психолого-педагогические аспекты методического наследия Лобачевского: актуальность и значимость. Н. И. Лобачевский и математическое образование в России. Материаль Международного форума по математическому образованию, посвящённого 225-летию Н. И. Лобачевского (Казань, 18-22 октября 2017 2.). 1, 28-36. Retrieved from http://dspace.kpfu.ru/xmlui/bitstream/handle/net/ 117676/F_IFME_2017_1_28_36.pdf?sequence=-1\&isAllowed=y.

Якиманская, И. С., \& Карымова, О. С. (2009). Семантический психогеометрический mест. Оренбург: Оренбургский государственный университет. 